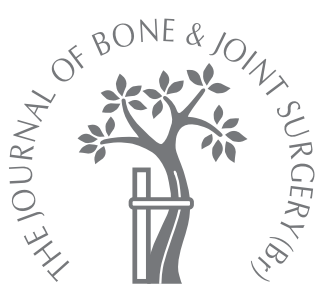

N. Tsumara,

S. Yoshiya,

T. Chin,

R. Shiba,

K. Kohso,

M. Doita

From Hyogo

Rehabilitation Center

and Kobe University

Graduate School of

Medicine, Kobe,

Japan
N. Tsumara, MD,

Orthopaedic Surgeon

T. Chin, MD, Orthopaedic

Surgeon

R. Shiba, MD, Orthopaedic

Surgeon

K. Kohso, MD, Orthopaedic

Surgeon

Hyogo Rehabilitation Center, 1070 Akebono-cho Nishi-ku,

Kobe 651-2181, Japan.

S. Yoshiya, MD,

Orthopaedic Surgeon

M. Doita, MD, Orthopaedic

Surgeon

Kobe University Graduate

School of Medicine, 7-5-2

Kusunoki-cho chyuou-ku,

Kobe 650-0017, Japan.

Correspondence should be sent to Dr N. Tsumara;

e-mail:

tsumuranob@nifty.com

C2006 British Editorial

Society of Bone and

Joint Surgery

doi:10.1302/0301-620X.88B1.

$16653 \$ 2.00$

$J$ Bone Joint Surg [Br]

2006;88-B:49-53.

Received 20 April 2005

Accepted after revision

6 September 2005

\title{
A prospective comparison of clamping the drain or post-operative salvage of blood in reducing blood loss after total knee arthroplasty
}

\begin{abstract}
We undertook a prospective, randomised study in order to evaluate the efficacy of clamping the drains after intra-articular injection of saline with 1:500 000 adrenaline compared with post-operative blood salvage in reducing blood loss in 212 total knee arthroplasties. The mean post-operative drained blood volume after drain clamping was $352.1 \mathrm{ml}$ compared to $662.3 \mathrm{ml}$ after blood salvage $(p<0.0001)$. Allogenic blood transfusion was needed in one patient in the drain group and for three in the blood salvage group. Drain clamping with intra-articular injection of saline with adrenaline is more effective than post-operative autologous blood transfusion in reducing blood loss during total knee arthroplasty.
\end{abstract}

Patients undergoing total knee arthroplasty (TKA) require blood transfusion. Although the incidence is low, serious complications involving homologous blood transfusions, such as viral infections and graft versus host disease, have been reported. ${ }^{1}$ Blood transfusion also involves additional cost so a reduction in its use is important in the peri-operative period. There are two current methods for avoiding homologous blood transfusions. One is by autologous blood transfusion, including preoperative autologous donation, intra-operative autologous transfusion and post-operative blood salvage. ${ }^{2-8}$ The other is a reduction in blood loss using techniques such as hypotensive anaesthesia, ${ }^{9}$ drain clamping, ${ }^{10-13}$ use of fibrin tissue adhesive, ${ }^{14,15}$ compression bandaging and cryotherapy. ${ }^{16}$

When a TKA is performed with the use of a tourniquet, most blood loss occurs after surgery. Among the various management strategies to deal with post-operative bleeding, several papers have described the efficacy of the post-operative collection and reinfusion of shed blood..$^{2-8}$ Recently, drain clamping has received increasing attention. ${ }^{10-13}$
In 1988, Sakihara et $\mathrm{al}^{10}$ reported a method of reducing post-operative bleeding whereby saline was injected through a drain tube after wound closure and the tube was then clamped for one hour. Since then further papers addressing drain clamping in TKA have been published in the English literature ${ }^{11-13}$ (Table I). In 1997, Ryu et $\mathrm{al}^{11}$ showed that infusion of saline with adrenaline reduced post-operative bleeding in comparison with saline alone. Yamada et $\mathrm{al}^{12}$ compared one-hour and 24hour drain clamping after TKA. They concluded that the haemostatic effects were similar for each but that there were significantly more complications after 24-hour clamping. They recommended clamping for one hour to minimise complications. ${ }^{12}$ Meanwhile, Kiely et $\mathrm{al}^{13}$ clamped drains for two hours without infusion of saline and reported no significant differences in blood loss and post-operative haemoglobin levels between the clamping group and controls. Consequently, the efficacy of drain clamping in post-operative management and the effect of the additional use of adrenaline on the reduction of bleeding, has not been clarified. No study has compared

Table I. Studies of drain clamping in total knee arthroplasty (TKA)

\begin{tabular}{lllllll}
\hline Authors & $\begin{array}{l}\text { Number } \\
\text { of TKA }\end{array}$ & $\begin{array}{l}\text { Clamp time } \\
\text { (hrs) }\end{array}$ & $\begin{array}{l}\text { Volume of } \\
\text { saline }(\mathbf{m l})\end{array}$ & $\begin{array}{l}\text { Adrenaline } \\
\text { concentration }\end{array}$ & $\begin{array}{l}\text { Mean intra-operative } \\
\text { volume of blood loss } \\
(\mathbf{m l})\end{array}$ & $\begin{array}{l}\text { Mean post-operative } \\
\text { volume of drained } \\
\text { blood (ml) }\end{array}$ \\
\hline${\text { Ryu et al }{ }^{11}}^{11}$ & 116 & 20 & 50 & $1: 200000$ & - & 207 \\
Yamada et al $^{12}$ & 22 & 1 & 50 & $1: 200000$ & 215 & 247 \\
& 22 & 24 & 50 & $1: 200000$ & - & 806 \\
Kiely et al $^{13}$ & 31 & 2 & 0 & - & - & 352 \\
Current study & 106 & 0.5 & 30 & $1: 500000$ & - &
\end{tabular}


Table II. Patient profiles

\begin{tabular}{llllll}
\hline Group & $\begin{array}{l}\text { Number of } \\
\text { patients }\end{array}$ & Men:women & $\begin{array}{l}\text { Mean age at operation } \\
\text { in yrs (SD) }\end{array}$ & Osteoarthritis & Osteonecrosis \\
\hline Drain clamping & 106 & $13: 93$ & $72.8(6.4)$ & 102 & 4 \\
Blood salvage & 106 & $10: 96$ & $72.6(6.1)$ & 103 & 3 \\
\hline
\end{tabular}

Table III. Associated comorbidities

\begin{tabular}{llllllll}
\hline Group & $\begin{array}{l}\text { Heart } \\
\text { disease }\end{array}$ & $\begin{array}{l}\text { Diabetes } \\
\text { mellitus }\end{array}$ & Hemiplegia & $\begin{array}{l}\text { Parkinson's } \\
\text { disease }\end{array}$ & Hepatitus & $\begin{array}{l}\text { Pigmentary degeneration } \\
\text { Asthe retina }\end{array}$ \\
\hline Drain clamping & 10 & 8 & 1 & 2 & 1 & 3 & 0 \\
Blood salvage & 12 & 8 & 2 & 2 & 2 & 1 & 1
\end{tabular}

drain clamping with other post-operative measures to control post-operative bleeding. The object of this prospective, randomised study was to evaluate the efficacy of drain clamping after intra-articular injection of saline with adrenaline, as compared with reinfusion of blood collected postoperatively, in reducing blood loss in TKA.

\section{Patients and Methods}

This was a prospective, randomised study. All patients undergoing TKA between April 1999 and July 2001 were enrolled. Those with rheumatoid arthritis, revision TKA and simultaneous bilateral TKA were excluded. Patients were alternately assigned to one of two groups. In the first, drain clamping was performed after injection of saline with adrenaline $(1: 500000)$ into the knee joint. A 16-gauge plastic needle was connected to the drain tube and a retrograde injection of saline with adrenaline was performed. In the second, post-operative blood salvage was used. The number of patients, the ratio of men to women, the age at operation, diagnosis and comorbidity were comparable and are described in Tables II and III. Predonation of autologous blood was not carried out for any patient.

We operated on six knees under a general anaesthetic, and the remaining 206 knees under spinal anaesthesia. All TKAs were unilateral using a medial parapatellar approach and a tourniquet. The tourniquet was not released before skin closure. For bony resection, an intramedullary alignment jig was used for the femur with an extramedullary device for the tibia. In 68 the patella was resurfaced and in 144 it was not. The posterior cruciate ligament was resected in 52 TKAs and retained in 160. The types of implant used were: Scorpio (Howmedica Osteonics Corp., Mahwah, New Jersey) in 75 knees, PFC Sigma (Depuy Orthopaedics Inc., Warsaw, Indiana) in 69, 7000 series (Howmedica Osteonics Corp.) in 30, LCS (Depuy; Johnson and Johnson) in 14, Advance (Wright Medical Technology Inc., Arlington, Tennessee) in 13 and Interax (Howmedica Osteonics Corp.) in 11. Hybrid fixation was used in 175 TKAs and full cementation in 37.

Post-operative management. In the drain clamping group, immediately after wound closure $30 \mathrm{ml}$ saline containing 1:500 000 adrenaline was injected through a $3.2-\mathrm{mm}$ diam- eter Port-VAC (Howmedica International SdeRL, Limerick, Ireland) drain. The drain tube was attached to a Y-connector which had a tube of $6.4 \mathrm{~mm}$ in diameter leading to the bellows. This tube was clamped and closed completely for 30 minutes, then the clamp was partially released until saline and blood started to flow out. If the flow of saline and blood ceased, the clamp was further opened until saline and blood flowed once again. Finally the clamp was fully opened. Shed blood was not re-infused. During release of the clamp, the volume of blood drained and the patient's general condition were carefully monitored.

In the blood salvage group, the ConstaVac blood conservation system 2 (Stryker Instruments, Kalamazoo, Michigan) was used. Blood was collected through a drainage tube of $4.8 \mathrm{~mm}$ in diameter. In all TKAs in this group, a battery pump was used for the evacuation of blood, and a low suction pressure was chosen. The blood passed through a 200 $\mu \mathrm{m}$ filter on its way to the $800 \mathrm{ml}$ sterile reservoir in order to remove gross debris. In the reservoir, blood was not mixed with a citrate anticoagulant but was re-infused into the patient within six hours of surgery. After re-infusion of the salvaged blood, the suction switch was turned off, while the drain remained in place for 48 hours.

In both groups, only one drain was placed deep to the fascia in the knee joint. A superficial drain was not used for any TKA. In both groups, the drains were removed at 48 hours and the volume of remaining fluid was measured. Continuous passive motion began after removal of the drains. For the prevention of deep-vein thrombosis, an arteriovenous impulse system (Novamedix, Andover, Hampshire, UK) was used in all patients.

Assessment. We reviewed the patient's notes, and recorded the volume of drained blood, the rate of allogenic blood transfusion, and the pre- and post-operative haemoglobin levels. The haemoglobin level was measured before surgery and at one day, one week and one month after the procedure. The re-infusion rate of retrieved blood and the volume of re-infused blood was evaluated in the blood salvage group. The operation time and the pre- and post-operative ranges of movement were also recorded, while alignment in the coronal plane was assessed on a standing anteroposterior radiograph. 
Table IV. Mean (SD) change in haemoglobin level over time for the two groups (g/dl)

\begin{tabular}{lllll}
\hline & \multicolumn{4}{l}{ Post-operatively } \\
\cline { 4 - 5 } Group & Pre-operative value (g/d $)$ & $\mathbf{1}$ day (g/dl) & 1 week (g/dl) & 1 month (g/dl) \\
\hline Drain clamping & $12.8(1.2)$ & $10.5(1.2)$ & $9.6(1.3)$ & $10.7(1.2)$ \\
Blood salvage & $12.7(1.3)$ & $10.5(1.2)$ & $9.8(1.3)$ & $10.9(1.3)$ \\
p value & 0.41 & 0.57 & 0.35 & 0.33 \\
\hline
\end{tabular}

* $p$ value is the comparison between two groups; $p<0.01$ considered significant

Table V. Mean (SD) post-operative reduction in the haemoglobin level for the two groups (g/dl)

\begin{tabular}{llll}
\hline Group & $\begin{array}{l}\text { Pre-operative to } \mathbf{1} \\
\text { day post-operative }\end{array}$ & $\begin{array}{l}\text { From 1 day to 1 } \\
\text { week post-operative }\end{array}$ & $\begin{array}{l}\text { From 1 week to 1 } \\
\text { month post-operative }\end{array}$ \\
\hline Drain clamping & $2.4(0.8)$ & $0.83(0.8)$ & $-1.1(0.8)$ \\
Blood salvage & $2.1(1.0)$ & $0.80(0.9)$ & $-1.2(1.0)$ \\
p value* & 0.03 & 0.78 & 0.58 \\
\hline
\end{tabular}

* $p$ value is the comparison between two groups; $p<0.01$ considered significant

Table VI. Mean (SD) pre- and post-operative radiographic alignment and operating time for the two groups

\begin{tabular}{lllc}
\hline Group & $\begin{array}{l}\text { Pre-operative varus } \\
\text { alignment }\left({ }^{\circ}\right)\end{array}$ & $\begin{array}{l}\text { Post-operative varus } \\
\text { alignment }\left({ }^{\circ}\right)\end{array}$ & $\begin{array}{l}\text { Operating time } \\
\text { (mins) }\end{array}$ \\
\hline Drain clamping & $5.7(7.2)$ & $-5.2(4.1)$ & $110(14)$ \\
Blood salvage & $3.8(8.7)$ & $-5.3(4.4)$ & $110(16)$ \\
p value $^{*}$ & 0.09 & 0.85 & 0.98 \\
\hline
\end{tabular}

* $p$ value is the comparison between two groups; $p<0.01$ considered significant

Table VII. Mean (SD) pre- and post-operative ranges of knee movement $\left({ }^{\circ}\right)$ for the two groups

\begin{tabular}{llllll}
\hline Group & $\begin{array}{l}\text { Pre-operative knee } \\
\text { extension (angle) }\end{array}$ & $\begin{array}{l}\text { Pre-operative knee } \\
\text { flexion (angle) }\end{array}$ & $\begin{array}{l}\text { Period from surgery to } \\
\text { measurement (days) }\end{array}$ & $\begin{array}{l}\text { Post-operative knee } \\
\text { extension (angle) }\end{array}$ & $\begin{array}{l}\text { Post-operative } \\
\text { knee flexion } \\
\text { (angle) }\end{array}$ \\
\hline Drain clamping & $-12.5(13.4)$ & $116.0(16.5)$ & $83.1(41.1)$ & $-4.2(6.5)$ & $107.5(14.6)$ \\
Blood salvage & $-10.0(7.9)$ & $115.5(19.0)$ & $80.0(31.0)$ & $-4.3(5.9)$ & $105.4(14.0)$ \\
p value $^{*}$ & 0.11 & 0.83 & 0.40 & 0.91 & 0.31 \\
\hline
\end{tabular}

* $p$ value is the comparison between two groups; $p<0.01$ considered significant

Data analysis. One-way analysis of variance (ANOVA) was used to analyse the difference in post-operative blood loss and the change in haemoglobin levels over time. A chisquared analysis was used to assess the difference in the rates of patients requiring allogenic blood transfusions. All differences were considered to be significant when $\mathrm{p}<0.01$. Statistical analysis was performed on a personal computer using Statview 4 (Abacus Concepts, Inc., Berkeley, California).

\section{Results}

The mean post-operative volume of drained blood was $352.1 \mathrm{ml}$ (SD 130.7; 100 to 770) in the clamping group and $662.3 \mathrm{ml}$ (SD 333.6; 15 to 1540) in the blood salvage group. This difference was significant $(\mathrm{p}<0.0001)$. Allogenic blood transfusion was required for one patient $(0.9 \%)$ in the clamping group and for three $(2.8 \%)$ in the blood salvage group although this difference was not significant $(\mathrm{p}=0.62)$.

The change in haemoglobin level over time was compared for the 208 patients who did not receive banked blood. The mean pre-operative haemoglobin level was similar for both groups. By the first post-operative day the haemoglobin level had decreased to $82 \%$ of its pre-operative level in the drain clamping group and to $83 \%$ for blood salvage. By one week after surgery, these values had declined to $75 \%$ and $77 \%$, respectively. Thereafter, the haemoglobin level gradually recovered (Table IV). The postoperative reduction in haemoglobin level for the two groups is shown in Table V. No significant difference was found between them at any time after operation.

In the blood salvage group drained blood was re-infused in 76 patients $(71.7 \%)$. No adverse reaction which required cessation of the blood transfusion was seen. The mean volume of blood re-infused was $415.1 \mathrm{ml}$ (SD 133.8; 80 to 680 ), equivalent to $72.7 \%$ of the total volume of drained blood.

Alignment on the coronal plane and the range of movement were similar for both groups with no significant difference found (Tables VI and VII). One patient with a nonfatal pulmonary embolism and one with an acute myocardial infarction were seen in the blood salvage group. In the 
Table VIII. Studies of post-operative unwashed blood salvage after unilateral total knee arthroplasty (TKA)

\begin{tabular}{|c|c|c|c|c|c|}
\hline Authors & $\begin{array}{l}\text { Number } \\
\text { of TKA }\end{array}$ & $\begin{array}{l}\text { Volume of salvaged } \\
\text { blood (ml) }\end{array}$ & $\begin{array}{l}\text { Volume of drained } \\
\text { blood (ml) }\end{array}$ & $\begin{array}{l}\text { Salvaged-drained } \\
(\%)\end{array}$ & Device used ${ }^{*}$ \\
\hline Gannon et $\mathrm{al}^{3}$ & 32 & 152 & - & - & Solcotrans ${ }^{*}$ \\
\hline Clements et $\mathrm{al}^{4}$ & 12 & 475 & 544 & 87.3 & Solcotrans \\
\hline Martin et $\left.a\right|^{5}$ & 153 & 829 & 1406 & 58.1 & $\begin{array}{l}\text { Solcotrans } \\
\text { ConstaVac }^{\dagger}\end{array}$ \\
\hline Han and Shin ${ }^{6}$ & 39 & 883 & 1193 & 74.0 & ConstaVac \\
\hline Adalberth et $\mathrm{al}^{7}$ & 24 & 353 & 881 & 40.1 & Solcotrans \\
\hline Sinha et $a l^{8}$ & 50 & 566 & 768 & 73.7 & Betatrans $^{\ddagger}$ \\
\hline Current study & 106 & 415 & 662 & 62.7 & ConstaVac \\
\hline
\end{tabular}

clamping group, there were three patients with a non-fatal pulmonary embolism. Post-operatively, no specific complications, such as haemolysis or infection, were seen in either group. No revision arthroplasty has been performed in either group.

\section{Discussion}

Drain clamping and post-operative blood salvage are the most commonly used methods for management for postoperative bleeding in TKA. In this prospective study, we examined both methods for efficacy and safety.

The rate of allogenic blood transfusion in TKA was reported as $8 \%$ by Keating et $\mathrm{al}^{17}$ and $13 \%$ by Bierbaum et $\mathrm{al}^{18}{ }^{18}$ even though approximately half of their patients donated blood pre-operatively. In our study, only $2.8 \%$ of the patients in the blood salvage group and $0.9 \%$ in the drain clamping group required allogenic blood transfusion. Compared with the results of previous studies, ${ }^{17,18}$ our rate of allogenic blood transfusion was very low in both groups. Consequently, both methods appear to reduce post-operative blood loss successfully.

Several papers have reported that the salvage of unwashed red blood cells after TKA is of benefit in unilateral TKA where the volume salvaged varies between 152 and $883 \mathrm{ml}$ (Table VIII). ${ }^{3-8}$ Our salvage volume of $415.1 \mathrm{ml}$ is similar to these amounts. In post-operative autologous transfusion, tissue debris, plasma-free haemoglobin, phospholipids, methylmethacrylate ${ }^{19}$ and other potentially toxic substances ${ }^{20}$ can be suctioned from the wound and transfused with the blood. As a result, post-operative autologous blood transfusion has potential dangers.

In contrast, the drain clamping method is easier than post-operative autologous blood transfusion and has, potentially, a lower risk of complications. The addition of adrenaline may further increase its ability to control bleeding; we observed no adverse effects of its use in our study.

We found no significant difference between our two groups either in their pre-operative condition or post-operative results. Only one patient $(0.9 \%)$ in the drain clamping group required allogenic blood transfusion while three $(2.8 \%)$ received allogenic blood transfusion in the blood salvage group. Consequently, blood salvage did not lead to a reduction in post-operative blood loss. Cost analysis revealed that drain clamping was financially more efficient than post-operative blood transfusion. In Japan, the ConstaVac Blood Conservation System 2 costs 25200 yen and the Port-VAC costs 6120 yen, making blood conservation four times more expensive. When the additional cost and trouble required for the use of the blood salvage system is taken into account, it appears that drain clamping is more efficient post-operatively than blood salvage.

However, some technical issues still remain with the drain clamping method. In previous studies, the concentration of adrenaline, the volume of saline used and the clamp time employed were different, so optimum levels for these parameters need to be established. In spinal surgery, in order to reduce bleeding, infiltration of the paraspinal soft tissues with 200 to $500 \mathrm{ml}$ of 1:500 000 adrenaline has been widely used. ${ }^{21}$ In TKA, Ryu et $\mathrm{al}^{11}$ and Yamada et al ${ }^{12}$ used saline containing 1:200 000 adrenaline when drain clamping. Meanwhile, Olszewski et $\mathrm{al}^{22}$ reported the effective use of 1:1 000000 adrenaline saline irrigation during routine arthroscopic knee surgery for control of bleeding. Our concentration of adrenaline was 1:500 000, approximately the centre of the reported range. Lower concentrations of adrenaline in saline are preferable in order to protect the systemic circulation. Our choice of a 1:500 000 concentration appeared to be reasonably successful in terms of both efficacy and safety.

The volume of injected saline in the previous reports has varied from 0 to $50 \mathrm{ml}^{10-13}$ During our operation for TKA the knee joint was incised and a soft-tissue release performed in order to correct any deformity in the majority of patients. During our study, small amounts of saline leaked through the skin incision at the time of the injection in some of our patients even with a $30 \mathrm{ml}$ volume. We therefore considered $30 \mathrm{ml}$ to be a sufficiently large volume to raise the intra-articular pressure; further increases in saline volume were not thought to be of additional benefit.

Debate still surrounds the length of time for which the drain should be closed. Larsson, Lewis and Liljedahl ${ }^{23}$ reported that when the tourniquet was released, reactive blood flow increased with the peak flow appearing within five minutes. During this period, it is important to decrease bleeding by the use of both a high intra-articular pressure of saline and the vasoconstrictive effects of adrenaline. 
Although the period of time for the drain to be closed remains controversial, between one and 24 hours has been reported previously. ${ }^{10-13}$ In general, the longer the duration of complete closure, the greater the risk of haematoma. Consequently, we felt that the period of complete drain closure should be kept to a minimum.

It is also important to maintain the intra-articular pressure sufficiently high for several hours after the drain is opened. However, there have been no discussions in earlier studies as to how the clamp should be released. If it is fully opened immediately, the intra-articular pressure rapidly declines and bleeding increases. Therefore, we recommend that the clamp is opened gradually. We believe this is important in reducing bleeding and avoiding an excessive accumulation of blood in the joint. It may also be important in reducing the influence of haemodynamics. For example, a case of transient hypotension upon release of the drain was reported by Kiely et al. ${ }^{13}$

Based on our own results, we recommend injection into the drain tube of $30 \mathrm{ml}$ saline containing 1:500 000 adrenaline and complete drain closure for 30 minutes, followed by gradual release of the clamp. Both techniques used in our study are commonly employed methods for managing blood loss after TKA in our country. Although drain clamping appeared to be advantageous over blood salvage, our evaluation was limited to the early post-operative haemodynamics and complications. The precise efficacy of these techniques could not be clarified as we made no comparison between our treatment groups and groups with other, conventional post-operative techniques. Further studies, including the subsequent clinical results of our two study groups, are required.

No benefits in any form have been received or will be received from a commercial party related directly or indirectly to the subject of this article.

\section{References}

1. Fiebig E. Safety of the blood supply. Clin Orthop 1998;357:6-18.

2. Groh GI, Buckert PK, Allen WC. A comparison of transfusion requirements after total knee arthroplasty using the Solcotrans autotransfusion system. J Arthroplasty 1990;5:281-5

3. Gannon DM, Lombardi AV Jr, Mallory TH, et al. An evaluation of the efficacy of postoperative blood salvage after total joint arthroplasty: a prospective randomized trial. J Arthroplasty 1991;6:109-14.
4. Clements DH, Sculco TP, Burke SW, Mayer K, Levine DB. Salvage and reinfusion of postoperative sanguineous wound drainage: a preliminary report. J Bone Joint Surg [Am] 1992;74-A:646-51.

5. Martin JW, Whiteside LA, Milliano MT, Reedy ME. Postoperative blood retrieval and transfusion in cementless total knee arthroplasty. J Arthroplasty 1992;7:205-10.

6. Han CD, Shin DE. Postoperative blood salvage and reinfusion after total joint arthroplasty. J Arthroplasty 1997;12:511-16.

7. Adalberth G, Bystrom S, Kolstad K, Mallmin H, Millbrink J. Postoperative drainage of knee arthroplasty is not necessary: a randomized study of 90 patients. Acta Orthop Scand 1998;69:475-8.

8. Sinha A, Sinha M, Burgert S. Reinfusion of drained blood as an alternative to homologous blood transfusion after total knee replacement. Int Orthop 2001;25: 257-9.

9. Juelsgaard P, Larsen UT, Sorensen JV, Madsen F, Soballe K. Hypotensive epidural anesthesia in total knee replacement without tourniquet: reduced blood loss and transfusion. Reg Anesth Pain Med 2001;26:105-10.

10. Sakihara $\mathbf{H}$, et al. A method to control postoperative bleeding after total knee replacement. Seikei-saigaigeka 1988;31:543-5 (in Japanese).

11. Ryu J, Sakamoto A, Honda T, Saito $\mathbf{S}$. The postoperative drain-clamping method for hemostasis in total knee arthroplasty: reducing postoperative bleeding in total knee arthroplasty. Bull Hosp Jt Dis 1997;56:251-4.

12. Yamada K, Imaizumi T, Uemura M, Takada N, Kim Y. Comparison between 1-hour and 24-hour drain clamping using diluted epinephrine solution after total knee arthroplasty. J Arthroplasty 2001;16:458-62.

13. Kiely N, Hockings M, Gambhir A. Does temporary clamping of drains following knee arthroplasty reduce blood loss?: a randomised controlled trial. Knee 2001;8: 325-7.

14. Wang GJ, Hungerford GS, Savory CG, et al. Use of fibrin sealant to reduce bloody drainage and hemoglobin loss after total knee arthroplasty: a brief note on a randomized prospective trial. J Bone Joint Surg [Am] 2001;83-A:1503-5.

15. Levy O, Martinowitz U, Oran A, Tauber C, Horoszwoski H. The use of fibrin tissue adhesive to reduce blood loss and the need for blood transfusion after total knee arthroplasty: a prospective, randomized, multicenter study. J Bone Joint Surg $[\mathrm{Am}]$ 1999;81-A:1580-8.

16. Gibbons CE, Solan MC, Ricketts DM, Patterson M. Cryotherapy compared with Robert Jones bandage after total knee replacement: a prospective randomized trial. Int Orthop 2001;25:250-2

17. Keating EM, Meding JB, Faris PM, Ritter MA. Predictors of transfusion risk in elective knee surgery. Clin Orthop 1998;357:50-9.

18. Bierbaum BE, Callaghan JJ, Galante J0, et al. An analysis of blood management in patients having a total hip or knee arthroplasty. J Bone Joint Surg [Am] 1999;81-A 2-10

19. Hand GC, Henderson $\mathbf{M}$, Mace $\mathbf{P}$, et al. Methylmethacrylate levels in unwashed salvage blood following unilateral total knee arthroplasty. J Arthroplasty 1998;13 576-9.

20. Handel M, Winkler J, Hornlein RF, et al. Increased interleukin-6 in collected drainage blood after total knee arthroplasty: an association with febrile reactions during retransfusion. Acta Orthop Scand 2001;72:270-2.

21. Tate DE Jr, Friedman RJ. Blood conservation in spinal surgery: review of current techniques. Spine 1992;17:1450-6.

22. Olszewski AD, Jones R, Farrell R, Kaylor K. The effect of dilute epinephrine saline irrigation on the need for tourniquet use in routine arthroscopic knee surgery. Am J Sports Med 1999;27:354-6.

23. Larsson J, Lewis DH, Liljedahl S0. Early biomechanical and hemodinamic changes after operation in a bloodless field. Eur Surg Res 1977:9:311-20. 